\title{
Social Science and the Public Interest
}

\author{
May/June 2020
}

Published online: 31 May 2020

(C) Springer Science+Business Media, LLC, part of Springer Nature 2020

\section{Editor's Note (1)}

The Review Symposium, "Howard Kaye's Freud as a Social and Cultural Theorist" for this issue (Vol. 57, No. 3) was originally sponsored by the "Picturing the Human Colloquy," part of the Institute for the Advanced Study of Culture at the University of Virginia on November 8, 2019, The Editor gratefully acknowledges the collaboration.

\section{Editor's Note (2)}

I am writing this in an unprecedented time, a time when very few capable of reasoning have not absorbed a new vocabulary of "global pandemic," "community spread," "mitigation," and "flattening the curve." The broad media have become the commentary vectors that are now reporting and analyzing the appearance, intensity, spread, and future of COVID-19, the acronym for Corona Virus Disease (2019). Amidst all this distress, I am sad to report that Society has lost five contributors, including two who were Advisory Board members. We know that at least one of these fine scholars, William B. Helmreich, died from the virus. In what follows are accounts of their contributions.

\section{Eugene Goodheart (1931-2020)}

Eugene Goodheart was an inveterate contributor to the pages of Society, spanning three decades with a total of nineteen articles and reviews. He was a literary critic, essayist, and public intellectual and served for many years as the Edytha Macy Gross Professor of the Humanities at Brandeis University where he directed the Brandeis Center for the Humanities. In these pages, he took on the problem of polarization in literature and politics, beginning with "Literary Study Left and Right" (Vol. 36, No. 2, 1999), in which he

criticized how ideological drumbeating had become the critical practice of too much literary criticism, to wit "My objection to the current state of the discipline is not so much to its political content, though I have my problems with it, as it is to the fact that it has established a virtual monopoly in the field, and that critical practice is too often devoid of literary sensibility. Rarely seen in the discourses nowadays is 'tact', a word used in the past to describe the delicate and complex engagement of a work by critical readers." He maintained, in his various assessments of biography, history, and politics, a commitment to complexity and "tact" that brought forth important and enduring judgments about political culture in general. Such efforts include "Tzvetan Todorov's Humanism" (Vol. 44, No. 3, 2007); "Neo-Darwinism and Religion" (Vol. 45, No. 2, 2008); “Two of a Kind" (Vol. 47, No. 1, 2010); "Deconstructing Left and Right: The Case for Bipartisanship" (Vol. 47, No. 4, 2010); "Light from Other Minds" (Vol. 48, No. 4, 2011); "Sports Allegory" (Vol. 48, No. 6, 2011); "Our Consuming Problem" (Vol. 49, No. 3, 2012); "Deal or No Deal" (Vol. 50, No. 3, 2013); "The Constitution: Dead or Alive" (Vol. 50, No. 6, 2013); "Between Liberty and Equality" (Vol. 51, No. 4, 2014); "Between Left and Right" (Vol. 53, No. 1, 2016); "Revolution: Removing its Halo" (Vol. 54, No. 2, 2017); “Trump's Cultural Populism” (Vol. 55, No. 1, 2018); "Russia Versus the West: A View from the Hard Left" (Vol. 55, No. 5, 2018); "Kazin, Bellow and Trilling: A Triptych" (Vol. 55, No. 6, 2018); "Conservatism in Trump Time" (Vol. 56, No. 3, 2019); "What We Talk and Don't Talk about When We Talk about Socialism” (Vol. 56, No. 5, 2019).

\section{Jeanne Guillemin (1943-2019)}

Jeanne Guillemin was an Advisory Board member until 1998. Her contributions included "Federal Policies and Indian Politics" (Vol. 17, No. 4, 1980); "The Price of Medical Heroics" (Vol. 19, No. 2, 1982); "The Business of 
Childbirth" (with Lynda Lytle Holmstrom) (Vol. 23, No. 5, 1986); "Planning to Die" (Vol. 25, No. 5, 1992). See also, (https:/www.washingtonpost.com/local/obituaries/jeanneguillemin-pioneering-researcher-who-uncovered-a-cold-warsecret-dies-at-76/2019/12/11/dfbc407e-1b66-11 ea-87f7f2e91143c60d_story.html) and (https://www.nytimes.com/ 2019/12/22/science/jeanne-guillemin-dead.html).

\section{S. Fred Singer (1924-2020)}

Noted for his contrarian assumptions and conclusions, in particular, about climate change, S. Fred Singer contributed two articles, "The Price System as a Control of Growth" (Vol. 15, No. 2, 1978) and "Benefits of Global Warming" (Vol. 29, No. 3, 1992). See also, https://www.nytimes.com/2020/04/11/ climate/s-fred-singer-dead.html and https://www.cfact.org/ 2020/04/07/fred-singer-a-giant-has-passed/

\section{Abigail Thernstrom (1936-2020)}

Abby Thernstrom was a member of the Advisory Editorial Board from 1998 to the present, and she contributed "RaceBased Programs and Good Schooling," (Vol. 37, No. 5, 2000). In the spirit that animated her life's work, coinciding with the mission of Society, she is quoted as saying: "I've got a problem with being stuffed into boxes ... Put me in a room of conservatives and I start running to the left; put me in a group of liberals and I start running to the right. I mean, I just have problems with ideologically coercive environments - I get claustrophobic." See also https:/www.nytimes.com/2020/04/ 20/us/abigail-thernstrom-dead.html?referringSource= articleShare and https://www.washingtonpost.com/local/ obituaries/abigail-thernstrom-conservative-voice-on-votingrights-and-education-dies-at-83/2020/04/14/07ed3478-7e5811ea-a3ee-13e1ae0a3571_story.html

\section{William B. Helmreich (1945-2020)}

Mary Curtis Horowitz, Chairman and Trustee of the Horowitz Foundation for Social Policy (www.horowitz-foundation.org), has graciously provided the following remembrance:

The sociologist William Helmreich died at home in Great Neck, New York on March 28, 2020. He was 74 years old, but far younger than the calendar would suggest. He was felled by the coronavirus pandemic sweeping the world, with the United States and the New York region the epicenter at that time. With his passing, the sociology profession lost a consummate ethnographer, one who opened closed worlds to a larger public. Generations of students lost a generous teacher. His wife Hennie lost her best friend, and their family a father and a grandfather. And I lost one of my oldest friends.

Born in Switzerland in 1945, Willy (as he was known to friends and colleagues) emigrated to the United States with his family after World War II ended. Willy lived in New York most of his life. He made the city not only his home, but the subject of one of his best-known books, The New York Nobody Knows (2013). It was so wellreceived that Willy followed it with books on New York's boroughs. His New York books married Willy's gifts as an ethnographer with the gregarious, curious, and fearless nature that defined him. He was a master at introducing himself to complete strangers, sometimes in situations some might find daunting, often discovering worlds that others never imagined. Willy loved his city, where he had grown up on the Upper West Side. For The New York Nobody Knows, he walked the city block by block, covering more than 6,000 miles alone or with students, friends, and sometimes with his wife Hennie. Then he did it all over again for the boroughs.

Willy was unabashedly intent on communicating with the widest possible audience. While he published some of his earlier books with major commercial firms, his goals were fulfilled with the New York books, all published with Princeton University Press. Though his New York books got more attention, Willy's academic work was well regarded. A son of Holocaust survivors who had made a successful life in this country, in Against All Odds (1992) he took the literature on survivors away from the image of damaged people with survivor guilt to focus on their lives as examples of triumph over adversity. Willy was also conversant with Orthodox Jewry and Yeshivas and revealed them to others in The World of the Yeshiva (1982). The Enduring Community (1998) is a fascinating exploration of the history of the Jewish community of Newark. His dissertation on a militant black group in 1960s St. Louis, later published as The Black Crusaders, was textbook ethnography. One of my personal favorites, The Things They Say Behind Your Back (1982), talked about the elements of truth that undergirds ethnic stereotype; it was politically incorrect, even for its time. In another book, What Was I Thinking, he explores what makes people do things that are incorrect, inappropriate, and likely to cause them trouble.

Willy and I met in a graduate seminar at Washington University taught by Irving Louis Horowitz, who became his mentor. Willy went on to get his $\mathrm{PhD}$ from that institution; I entered the world of publishing. We remained friends, and at Transaction Publishers, I came to appreciate Willy as an 
author. His articles and book reviews for SOCIETY address some of the themes that engaged him throughout his career: ethnicity, the Holocaust and the hidden world of the Yeshiva. In re-reading some of these articles, I was struck by words that seem to speak to our collective experience of the pandemic that took his life. Speaking of the Holocaust, Willy notes it is "a good case study of how human beings in general adjust to catastrophic events." And with respect to Orthodox Jews who survived, and their children, he observes "in addition to confronting the horror of the Holocaust itself, they are faced not only with re-creating the social fabric of their lives but also coming to grips with why God would permit such things to happen." I can't help wondering what Willy might have written about the societal impact of the pandemic, the costs to those who survive, and what it may take to establish a new normalcy.

[William Helmreich contributed the following to the pages of Society: "Black Crusaders: The Rise and Fall of Political Gangs" (Vol. 11. No. 5, 1973); "Making the Awful Meaningful" (Vol. 19, No. 4, 1982); and "Richard Alba: The Blurring of the Color Line" (Vol. 47, No. 3, 2010)].

Publisher's note Springer Nature remains neutral with regard to jurisdictional claims in published maps and institutional affiliations. 